Journal of Engineering and Applied Sciences 15 (4): 1027-1042, 2020

ISSN: 1816-949X

(C) Medwell Journals, 2020

\title{
Performance Characteristics of Building Integrated and Freestanding Photovoltaic System with Various PV Technologies and Angles: A Case Study in NEU Grand Library, North Nicosia
}

\author{
Youssef Kassem, Hüseyin Gokcekus and Ülker Burcu Filitoglu \\ Department of Civil Engineering, Faculty of Civil and Environmental Engineering, \\ Near East University, 99138 Nicosia (via. Mersin 10, Turkey), Cyprus
}

\begin{abstract}
Solar energy can be an important source in the Northern part of Cyprus part not only to add a new capacity but also to increase energy security, addressing the environmental concerns. Solar radiation can be considered constant in a wide area. Therefore, the objective of this study is to analyze the monthly global solar radiation, sunshine duration, relative humidity and average temperature collected from the Meteorology Department for North Nicosia to show the potential of solar energy in North Nicosia. The data were collected from 2008-2018 and measured at $2 \mathrm{~m}$ height. The results showed that global solar radiation data are within the range of 5.4-341.9 $\mathrm{kWhm}^{-2}$ and the mean annual global solar radiation is found to be $2437.52 \mathrm{kWhm}^{-2}$. In addition, it is found that sunshine duration in North Nicosia is varied from 7.94-12.967 h/day with an average of $8.4 \mathrm{~h} /$ day. Moreover, this study is aimed to investigate the performance characteristics of grid-connected Building Integrated Photovoltaic (BIPV) in North Nicosia as exemplified by NEU grand library. In this study, a $30 \mathrm{kWp}$ PV capacity is proposed based on the available roof and front of NEU grand library building and its performance in the BIPV system with various angles (slop and azimuth angles) and three PV technologies (crystalline, CIS and CdTe) is analyzed. Furthermore, the performance of freestanding mounting positions with various angles and PV technologies for roof building is studied and compared with BIPV systems. PVGIS simulation tool is used in this study. It concluded that among the proposed two systems, freestanding mounting position system performs better than BIPV and technology wise CdTe performs better than CIS and crystalline.
\end{abstract}

Key words: BIPV, freestanding system, NEU grand library, North Nicosia, solar energy, PV technologies

\section{INTRODUCTION}

Due to the growing populations, the number of the building has been increased that led to increase the energy consumption relies mainly on fossil fuel (Huovila, 2007; Chateau and Lapillonne, 1982; Sorrell, 2015). Consumption of fossil fuel leads to higher greenhouse gas emissions and air pollutions (Perera, 2018). In recent years, many of the studies are found that the use of renewable energy as a powerful energy source can reduce the total energy consumption and could potentially provide a promising solution for reducing the energy demand for urban building (Li and Loo, 2014; Owusu and Asumadu-Sarkodie, 2016; Chel and Kaushik, 2018; Vares et al., 2019; Liu et al., 2019b; Hossain, 2019; Harkouss et al., 2019).

One of the most promising renewable energy is solar energy. Solar energy is considered an effective alternative energy source because of its environmental benefits. Solar Photovoltaic (PV) applications are utilized to convert the sun's power to electric energy which used for power supply to the building. Recently, the use of a solar PV system for urban building has become more popular (Liu etal., 2019a; Lee et al., 2014; Heinstein et al., 2013). In this case, PV modules are integrated or attached to the building during the construction or after the construction phase. In addition, the integration of PV in the urban environment and building is proposed a huge potential such as environmental and economic benefits (Heinstein et al., 2013). The integration of PV in urban building is called Building Integrated Photovoltaic (BIPV). The BIPV can be integrated into the new or old building mainly into roof or facade which referred to as BIPV facades and BIPV-roof (Debbarma et al., 2016; Assi et al., 2009). BIPV products including transparent or semitransparent glass PV modules will be replaced by the old-style material of the building that used for constructing the roof or wall. In fact, the local weather conditions and the building architecture are important factors that affect the functionality of the BIPV system (Kumar et al., 2019a).

Numerous studies have been investigated the potential of BIPV in terms of environmental and economic benefits (Oliver and Jackson, 2001;

Corresponding Author: Youssef Kassem, Department of Mechanical Engineering, Faculty of Engineering, Near East University, 99138 Nicosia (via. Mersin 10, Turkey), Cyprus, Tel: +90 (392) 2236464 
Bonomo et al., 2017; Yang and Zou, 2016; Ng and Mithraratne, 2014; Li et al., 2013; Yang, 2015; Keoleian and Lewis, 2003). For example, Oliver and Jackson (2001) applied energy analysis and economic analysis to investigate the application of PV in the building. Bonomo et al. (2017) evaluated the cost-effectiveness of BIPV for building skin by using a multi-criteria approach. Yang and Zou (2016) identified the costs, benefits and risks of BIPV for greater BIPV applications.

Solar potential in Cyprus: Cyprus is an island that experiences a Mediterranean climate with huge potential for solar energy. Numerous studies have been investigated the potential of renewable energy in terms of solar energy and wind energy in Northern Cyprus. For instant, Ogbeba and Hoskara (2019) proposed PV as a shading device to reduce the heating problem in Northern Cyprus. They concluded that this system could be generated nearly $2800 \mathrm{~W}$ that can provide up to $50 \%$ of the electricity demand of the house. Ouria and Sevinc (2018) investigated the use of solar energy in Famagusta in Cyprus. The found that the rate of solar energy depends on the city's climatic, geographic features and other factors. Recently, Kassem etal. (2018) and (Fokaides and Kylili, 2014) studied the performance of $6.4 \mathrm{~kW}$ rooftop PV system for household buildings in three urban regions in Northern Cyprus. They found that the PV system has significant potential in reducing electricity consumption. Kassem and Gokcekus (2018) evaluated the techno-economic of the $1 \mathrm{MW}$ grid-connected PV system in Lefke, Northern Cyprus. The researchers concluded that this system could be reduced the $\mathrm{CO}_{2}$ emissions in the town. Kassem et al. (2018) evaluated and compared the techno-economic of $12 \mathrm{MW}$ grid-connectedPV plants and wind farms in two regions in Northern Cyprus. The results indicated that the PV system is the most economical option to generate electricity in Northern
Cyprus. Moreover, according to the Deputy Prime Minister and Ministry Foreign Affairs Northern Cyprus (DPMMFA., 2019), International Cyprus University has completed the greatest PV project for generating electricity in the university. They found that the system was meeting $80 \%$ of the electricity of the university during the daytime. Yenen et al. (DPMMFA., 2019) evaluated, modeled and compared two solar thermal energy systems over Northern Cyprus. The results demonstrated that the highest solar irradiation absorption and lower GHG emissions and cost for the Northern part of Cyprus were obtained from Fresnel system. Maltini and Minder (2015) Mohammadi et al. (2018) designed and built 1.275 MW grid-connected PV plant at Serhatkoy site in Northern Cyprus. Ozerdem et al. (2015) evaluated the performance ratio, capacity factor of Serhatkoy PV plant in Northern Cyprus.

Figure 1 shows the long-term averages of solar resources generated by global solar atlas map in Cyprus including global horizontal irradiation, optimum angle of PV module, diffuse horizontal irradiation, direct normal irradiation, air temperature and PV electricity output. It is found that the annual average of global horizontal irradiation of Northern Cyprus is varied from $1900-2100 \mathrm{kWhm}^{-2}$. The highest global horizontal irradiation is in the northwestern part of Northern Cyprus which ranged from $2000-2100 \mathrm{kWhm}^{-2}$. These results indicate the Northern part of Cyprus has hug solar energy that can be used to generate electricity. The second most significant climate variable to determine the performance of the solar system is air temperature. It is noticed that the air temperature is within a range of 20-24 as shown in Fig. 1. Moreover, it is observed that the optimum angle of the PV module is within the range of $30-40^{\circ}$ as shown in Fig. 1. The global solar atlas map is the most reliable source of data available that used to estimate the solar potential in the specific region. (a)

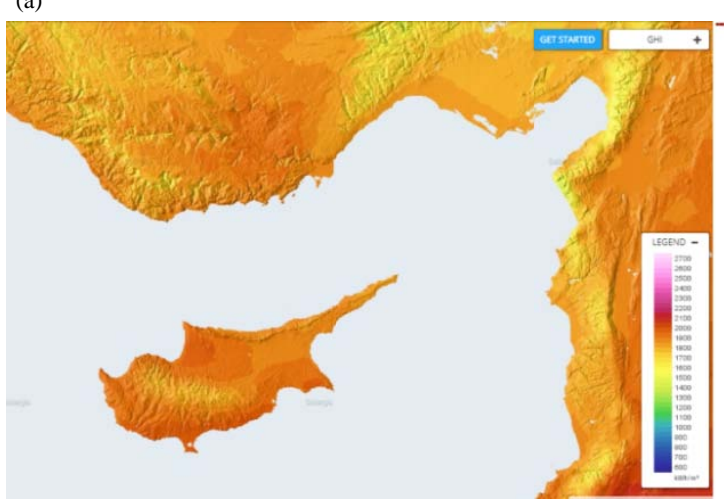

(b)

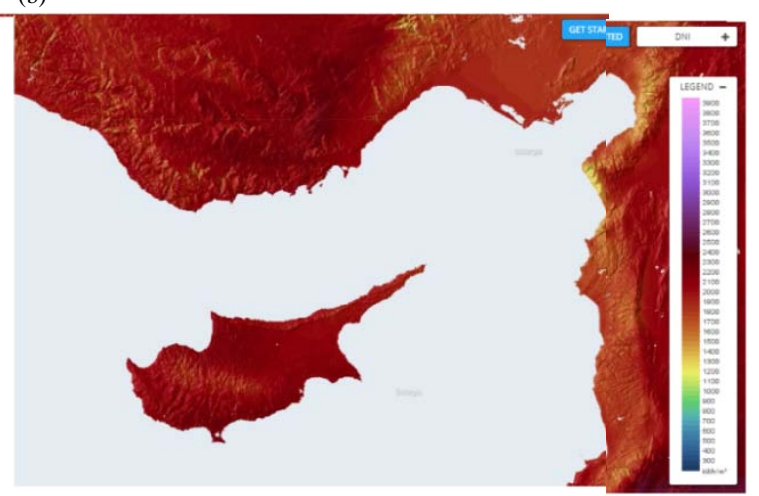

Fig. 1: Continue 
(c)

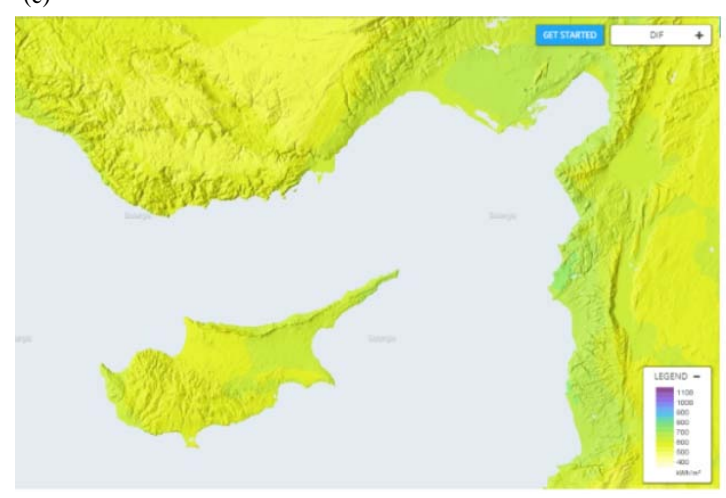

(e)

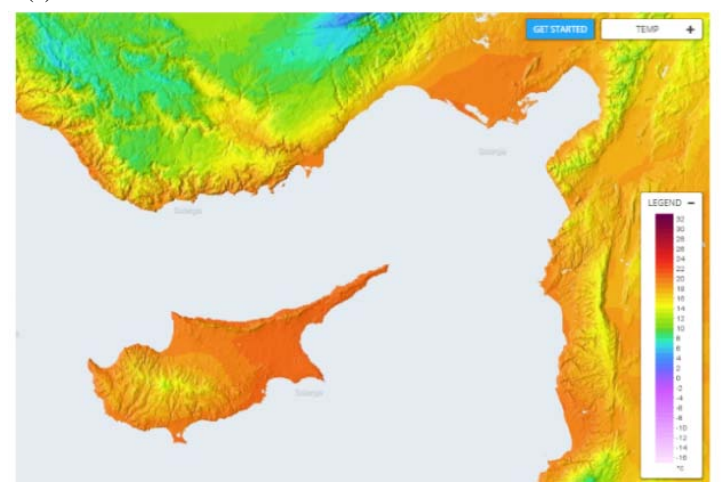

(d)

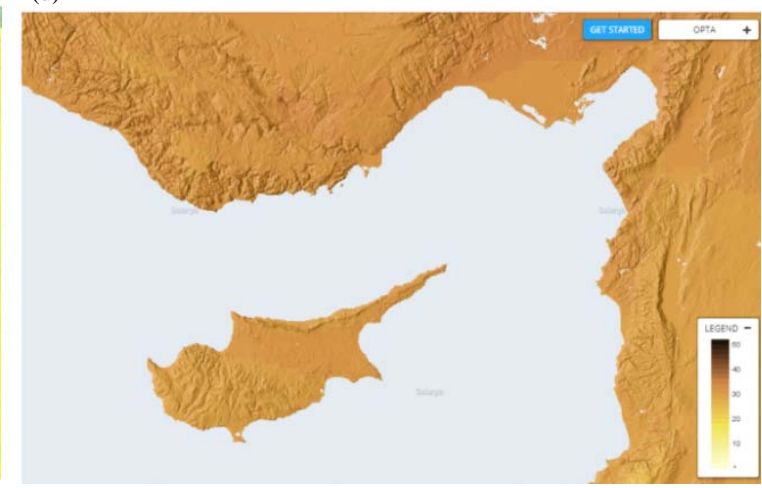

(f)

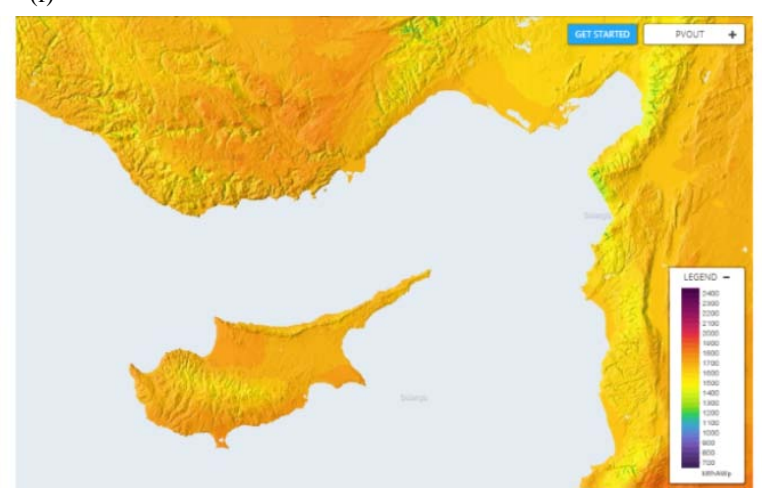

Fig. 1(a-f): Long-term averages of solar resource of Cyprus, (a) Global horizontal irradiation, (b) Direct normal irradiation, (c) Diffuse horizontal irradiation, (d) Optimum angle of PV module, (e) Air temperature and (f) PV electricity output

PV simulation software packages: In the field of solar PV system, a simulation method has been developed to study the solar energy potential at a specific region. Various studies have been investigated the solar potential using various simulation software packages such as PVGIS, PVWatts, RETScreen, Homer, PV*SOL and so on. For example, Kassem et al. (2018) and Ogbeba and Hoskara (2019) investigated the performance of a $6.4 \mathrm{~kW}$ rooftop PV system in three regions in Northern Cyprus using three simulation tools including PVGIS, PV*SOL and PVWatts. Sudhakar et al. (2016) investigated the feasibility of a $10 \mathrm{~kW}$ grid-connected PV system in India using Solargis PV Planner Software. Dondariya et al. (2018) analyzed the performance of $6.4 \mathrm{~kW}$ grid-connected rooftop of PV system using various software including $\mathrm{PV} * \mathrm{SOL}$, PVGIS, SolarGIS and SISIFO at in holy city Ujjain, India. Nassar and Alsadi (2019) evaluated the solar energy potential in Palestine using the System Advisor Model. Mohammadi et al. (2018) assessed the potential of $5 \mathrm{MW}$ gird-connected PV systems in different cities in the Southern coast of Iran using RETScreen Software. Pavlovic et al. (2013) compared the mean monthly of daily solar radiation for three different locations in Serbia by taken the data from NASA, RETScreen, PVGIS and HMIRS. Enongene et al. (2019) evaluated the potential of solar PV system in residential buildings in Lagos metropolitan area, Nigeria using HOMER Pro. Shahzad et al. (2017) evaluated the electricity cost of the hybrid system (PV/Biomass) for an agricultural farm and a residential community in Pakistan using HOMER Software. Bocca et al. (2016) estimated and compared the PV electricity for installations in Italy using measurement data and the PVGIS simulation tool. Chang and Starcher (2019) evaluated the energy production of $45 \mathrm{~kW}$ PV system in different location in Texas using PVWatts calculator. Psomopoulos et al. (2015) compared the performance of three simulation tools (PVGIS, PVWatts and RETScreen) for evaluating three roof-integrated PV systems in Greece. Hassaine and Mraoui (2017) proposed a grid-connected PV system in Algeria based on a database collected from PVGIS. Belkilani et al. (2018) and Hassaine and Mraoui (2017) analyzed the ground measurement monthly global solar radiation for three different locations in Tunisia and compared the actual data of global solar radiation with a database collected from PVGIS. Chakraborty et al. (2014) evaluated the performance of a $1 \mathrm{MW}$ solar PV system for 
(a)

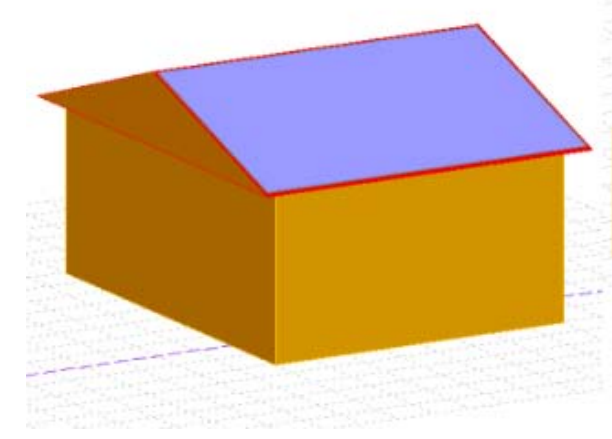

(b)

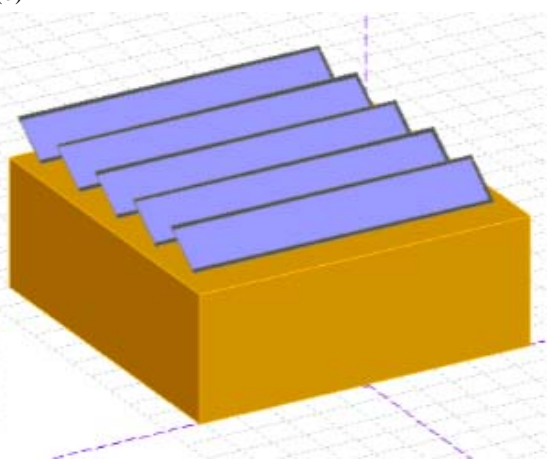

Fig. 2(a, b): (a) BIPV and (b) BAPV system

an energy efficient building in Bangladesh by utilizing NASA SSE solar radiation data, PVsyst simulation Software and RETScreen simulation Software. Ohijeagbon and Ajayi (2014) used HOMER and RETScreen Software to investigate the feasibility and economic viability of standalone hybrid systems for an off-grid rural community of Sokoto in North-West Nigeria. Assamidanov et al. (2018) utilized RETScreen Software to analyze the techno-economic feasibility of implementing a residential PV system in South Kazakhstan. Kumar et al. (2019b) studied the feasibility of $1 \mathrm{MW}$ PV system at Universiti Malaysia Pahang by utilizing two-simulation software PVWatts and PVGIS.

Building attached and building integrated photovoltaic systems: There are two basic types of PV systems used on building: Building Attached PV (BAPV) and Building-Integrated PV (BIPV) (Halbe et al., 2014). For the BAPV system, the PV models are installed on the surface of the building roofs with a certain inclined angle and they are supported by some superstructure while for BIPV system, the PV arrays are placed on the top of the building or to replace conventional building materials (Singh, 2013; Zomer et al., 2013; Henemann, 2008) as shown in Fig. 2. There are many studies have been concerned with BIPV and BAPV applications (Kumar et al., 2019a; Zomer et al., 2013; Bakos et al., 2003; Wu et al., 2015; Wang et al., 2016; Osseweijer et al., 2018; Salem and Kinab, 2015; Fina et al., 2019; Fouad et al., 2019; Zhou et al., 2017; Imenes, 2016). For instant, Kumar et al. (2019a) evaluated the performance of $32.7 \mathrm{kWp}$ PV for building application in two different configurations (BAPV and BiPV) with three various PV technologies using PVGIS simulation tool. Zomer et al. (2013) compared BIPV and BAPV applications on the envelopes of two different Brazilian airports. Bakos et al. (2003) evaluated the techno-economic of grid-connected BIPV system installed in Northern Greece. Wu et al. (2015) studied the performance monitoring of the first home-based grid-connected BAPV located in Shanghai, China. Wang et al. (2016) estimated the environmental impacts of $3 \mathrm{kWp}$ BAPV and $10 \mathrm{~kW}$ BIPV system in Shanghai, China. Salem and Kinab (2015) and Osseweijer et al. (2018) identified techniques and strategies that can be used today on buildings located in the Mediterranean region.

Objective of the study: The objectives of the study are as follows: to evaluate the validity of the simulated data in comparison with the meteorological data in North collected from meteorological department in North Nicosia. To investigate the applicability of PV system for NEU grand library building applications in two different configurations with various angles (slope and azimuth angles) (BIPV and freestanding systems) and to compare the performance of these systems. To recognize the best PV technology (crystalline, CIS, CdTe technology) for NEU grand library building in North Nicosia.

\section{MATERIALS AND METHODS}

Study location: Study location where BIPV system is proposed in Near East University (NEU) in practically NEU Grand Library. It is located in North Nicosia of Cyprus at a latitude of $35.255^{\circ} \mathrm{N}$, longitude of $33.327^{\circ} \mathrm{E}$. Moreover, Fig. 3 shows a panoramic view and architectural overview of NEU Grand Library as designed as two floors above ground and one underground building. Furthermore, the NEU Grand Library covers an area of $15000 \mathrm{~m}^{2}$ of interior space, this huge complex includes excellent library format and content on the island, Cyprus, not only in size but also with its extensive services. With regard to its physical dimensions and potential, the library has more than a million items printed on its open shelves. It is a center of culture and access to information built according to international standards including more than 150 million electronic articles, 700 computer tablets, 17 cinema booths, 12 personal and group study rooms, 4 seating stands of 1000 , theater of 350 people, cafeteria of 600 people and 600 study 
(a)

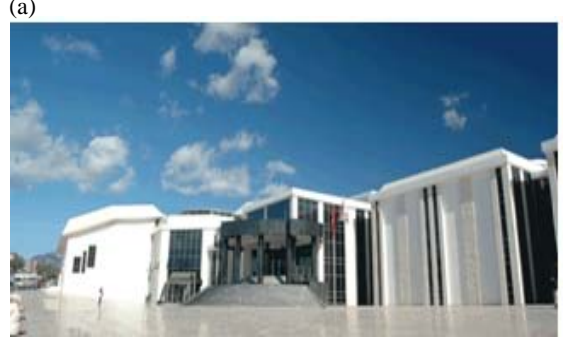

(c)

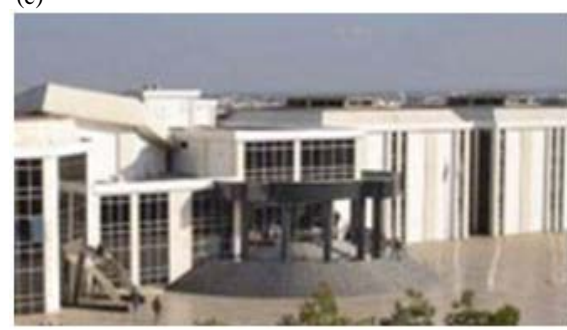

(b)

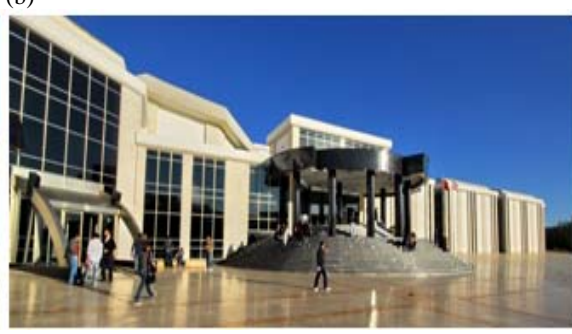

(d)

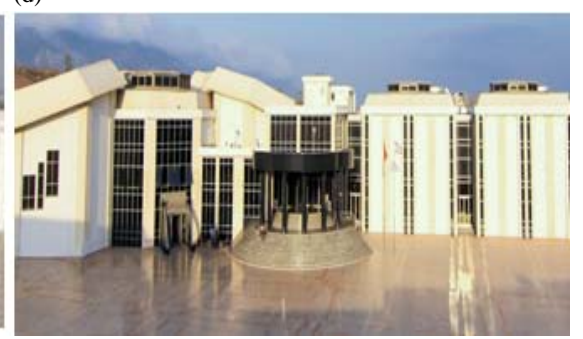

Fig. 3(a-d): Panoramic view of NEU Grand Library

\begin{tabular}{|c|c|c|c|}
\hline$\overline{\text { PV cell }}$ & & Efficiency & \\
\hline material & Cell color & $(\%)$ & Advantages \\
\hline Crystalline & $\begin{array}{l}\text { Dark blue, } \\
\text { black }\end{array}$ & $13-18$ & $\begin{array}{l}\text { Easily available and more } \\
\text { efficient photovoltaic cells }\end{array}$ \\
\hline CIS & Black & $10-12$ & $\begin{array}{l}\text { Less impact on the } \\
\text { performance due to } \\
\text { variations in temperatures } \\
\text { as well as shadow conditions }\end{array}$ \\
\hline CdTe & $\begin{array}{l}\text { Dark green, } \\
\text { black }\end{array}$ & $9-11$ & - \\
\hline
\end{tabular}

tables and $24 \mathrm{~h}$ free internet open $24 \mathrm{~h}$ a day. The photovoltaic modules are planned to incorporate into the building in BIPV.The capacity of the proposed system is estimated to as $30 \mathrm{kWp}$ and it is based on the available roof and front of the building.

Modeling of BIPV systems: In the present study, PVGIS is used to analyze the performance of the proposed $32.7 \mathrm{kWp}$ BIPV system. Generally, PVGIS used to analyze the performance of stand-alone, grid-connected and tracking PV systems for different locations in various installation configurations over the world. It also provides the irradiation in the form of TMY files in three different databases ranging from 2005-2014, 2006-2015 and 2007-2016. Hence, this tool with a large database of solar irradiance for major locations allows the users to calculate electricity potentials from the PV power plants with an option of selecting PV technologies installed at various tilt and azimuth angles. Moreover, three types of PV technologies are used. The comparison between these technologies is given in Table 1. Following the building special form, the BIPV plant was distributed to cover all the available space in the roof and four orientations of the building. In this study, horizontal and inclined PV systems are applicable on the roof and four orientations of the building.

Performance parameters: The performance of energy of BIPV system is evaluated by considering the following parameters:

- Location of the site

- Type of PV technology used

- Loss due to the angle of incidence, temperature and irradiance

In the current study, four major technical criteria are used for evaluating the performance of the BIPV system (Ayompe et al., 2011; Kumar et al., 2017; Sharma and Chande1, 2013; Okello et al., 2015; Sundaram and Babu, 2015; Sharma and Goel, 2017).

Reference Yield (RY):

$$
\mathrm{RY}=\frac{\text { In plane radiation on PV array in } \mathrm{kWhm}^{-2}}{\text { Global radiation at STC array in } \mathrm{kWhm}^{-2}}
$$

Yield Factor (YF):

$$
\mathrm{YF}=\frac{\begin{array}{c}
\text { Total amount of energy produced during } \\
\text { the period of operation in } \mathrm{kWh}
\end{array}}{\text { Installed capacity in } \mathrm{kWp}}
$$

Array Yield (AY):

$$
\mathrm{AY}=\frac{\text { Array output energy in } \mathrm{kWhd}^{-1}}{\text { Installed capacity in } \mathrm{kWp}}
$$


Capacity utilization factor (CF):

$$
\mathrm{CF}=\frac{\mathrm{YF}}{365 \times 24}
$$

Performance Ratio (PR):

$$
\mathrm{PR}=\frac{\mathrm{YF}}{\mathrm{RY}}
$$

\section{RESULTS AND DISCUSSION}

\section{Solar potential in North Nicosia}

Characteristics of meteorological parameters in North Nicosia: Solar radiation can be considered constant in a wide area (Bhatia, 2014). However, wind is a very local resource and it must be studied in the specific location and not in the region in which the wind turbine will be placed by considering that some locations in the region have more wind than the other area (EWEA., 2015). Therefore, solar potential and other meteorological parameters including temperature, humidity and sunshine duration for North Nicosia are studied. The data were collected from the meteorological department located in North Nicosia and measured at the height of $2 \mathrm{~m}$. In general, the accuracy of the satellite data is not enough to decide for designing a solar PV system (Argungu and Dabai, 2017; Huld, 2017). Therefore, to ensure the accuracy of the performance of PV solar system results based on satellite data, the solar radiation values collected from PVGIS were compared with the actual measurement of North Nicosia. Table 1 describes the location including geographical coordinates, altitude, measuring height and period of record.

Different statistical measures including the mean, Standard Deviation (SD), Coefficient of Variation (CV), minimum, median and maximum are calculated for each meteorological parameter. Table 2 shows the statistical

\begin{tabular}{|c|c|c|c|c|c|c|}
\hline Parameter/Year & Mean & SD & $\mathrm{CV}$ & Minimum & Median & Maximum \\
\hline \multicolumn{7}{|c|}{ Average temperature $\left[{ }^{\circ} \mathrm{C}\right]$} \\
\hline 2008 & 19.64 & 7.39 & 37.61 & 8.120 & 19.57 & 29.80 \\
\hline 2009 & 19.46 & 7.27 & 37.38 & 10.56 & 19.14 & 29.75 \\
\hline 2010 & 20.02 & 6.80 & 33.98 & 11.15 & 19.75 & 30.66 \\
\hline 2011 & 18.87 & 7.44 & 39.43 & 10.69 & 18.12 & 29.35 \\
\hline 2012 & 19.20 & 8 & 41.68 & 8.380 & 18.88 & 30.44 \\
\hline 2013 & 19.35 & 7.21 & 37.28 & 9.620 & 18.85 & 29.51 \\
\hline 2014 & 19.48 & 6.60 & 33.85 & 11.60 & 19.10 & 29.20 \\
\hline 2015 & 19.13 & 7.50 & 39.22 & 9.180 & 19.09 & 29.68 \\
\hline 2016 & 19.97 & 7.47 & 37.40 & 9.260 & 20.87 & 30.17 \\
\hline 2017 & 19.37 & 7.64 & 39.42 & 8.410 & 19.26 & 30.67 \\
\hline 2018 & 20.18 & 7.05 & 34.91 & 11.00 & 20.55 & 29.60 \\
\hline \multicolumn{7}{|c|}{ Maximum temperature $\left[{ }^{\circ} \mathrm{C}\right]$} \\
\hline 2008 & 27.11 & 8.04 & 29.67 & 14.32 & 27.26 & 38.30 \\
\hline 2009 & 26.54 & 8.11 & 30.57 & 16.40 & 27.00 & 37.34 \\
\hline 2010 & 27.73 & 7.76 & 27.98 & 16.64 & 27.90 & 39.72 \\
\hline 2011 & 26.04 & 8.29 & 31.82 & 16.43 & 24.95 & 38.06 \\
\hline 2012 & 26.50 & 8.83 & 33.33 & 14.55 & 26.89 & 38.33 \\
\hline 2013 & 26.88 & 7.93 & 29.49 & 15.83 & 26.80 & 38.07 \\
\hline 2014 & 26.77 & 7.06 & 26.37 & 17.90 & 26.85 & 37.70 \\
\hline 2015 & 26.55 & 8.32 & 31.34 & 15.04 & 26.69 & 37.80 \\
\hline 2016 & 27.39 & 8.29 & 30.26 & 14.89 & 29.18 & 38.21 \\
\hline 2017 & 26.87 & 8.43 & 31.36 & 14.58 & 26.52 & 39.17 \\
\hline 2018 & 26.58 & 8.24 & 31.02 & 14.10 & 26.80 & 37.30 \\
\hline \multicolumn{7}{|c|}{ Minimum temperature $\left[{ }^{\circ} \mathrm{C}\right]$} \\
\hline 2008 & 12.69 & 6.97 & 54.91 & 1.69 & 12.48 & 22.72 \\
\hline 2009 & 12.71 & 6.65 & 52.32 & 4.85 & 11.56 & 22.70 \\
\hline 2010 & 12.93 & 6.22 & 48.12 & 5.88 & 11.76 & 23.30 \\
\hline 2011 & 12.03 & 6.74 & 56.05 & 4.47 & 11.22 & 21.61 \\
\hline 2012 & 12.45 & 7.46 & 59.92 & 2.46 & 12.68 & 23.27 \\
\hline 2013 & 12.15 & 6.69 & 55.06 & 3.84 & 11.43 & 21.57 \\
\hline 2014 & 12.84 & 6.36 & 49.56 & 4.70 & 11.95 & 22.00 \\
\hline 2015 & 12.21 & 7.07 & 57.91 & 3.50 & 11.60 & 22.58 \\
\hline 2016 & 12.95 & 7.02 & 54.22 & 3.18 & 13.12 & 22.72 \\
\hline 2017 & 12.30 & 7.02 & 57.10 & 2.43 & 12.09 & 22.94 \\
\hline 2018 & 13.83 & 6.63 & 47.99 & 3.20 & 14.45 & 22.40 \\
\hline \multicolumn{7}{|c|}{ Sunshine duration [h/day] } \\
\hline 2008 & 8.718 & 2.182 & 25.03 & 5.731 & 8.288 & 12.967 \\
\hline 2009 & 8.189 & 2.551 & 31.15 & 4.397 & 8.319 & 11.873 \\
\hline 2010 & 8.332 & 2.299 & 27.59 & 4.384 & 8.605 & 11.603 \\
\hline 2011 & 8.288 & 2.038 & 24.59 & 5.268 & 7.940 & 11.552 \\
\hline
\end{tabular}

Table 2: Description of meteorological parameter in North Nicosia 
Table 2: Continue

\begin{tabular}{|c|c|c|c|c|c|c|}
\hline Parameters/Years & Mean & SD & $\mathrm{CV}$ & Minimum & Median & Maximum \\
\hline$\overline{2012}$ & 8.517 & 2.387 & 28.03 & 4.626 & 8.65 & 11.944 \\
\hline 2013 & 8.534 & 2.324 & 27.23 & 4.926 & 9.152 & 11.567 \\
\hline 2014 & 8.270 & 2.067 & 24.99 & 4.916 & 8.368 & 11.594 \\
\hline 2015 & 8.209 & 2.254 & 27.46 & 4.648 & 8.301 & 11.323 \\
\hline 2016 & 8.519 & 2.292 & 26.9 & 4.568 & 8.918 & 11.573 \\
\hline 2017 & 8.389 & 2.204 & 26.27 & 5.406 & 8.449 & 11.890 \\
\hline 2018 & 8.358 & 2.017 & 24.14 & 5.400 & 8.800 & 11.200 \\
\hline \multicolumn{7}{|c|}{ Global solar radiation $\left[\mathrm{kWhm}^{-2}\right]$} \\
\hline 2008 & 225.3 & 80.6 & 35.78 & 112.6 & 223.1 & 334.2 \\
\hline 2009 & 220.1 & 89.9 & 40.83 & 94.4 & 219.5 & 338.0 \\
\hline 2010 & 218.6 & 85.0 & 38.88 & 102.6 & 227.2 & 335.2 \\
\hline 2011 & 218.1 & 78.0 & 35.76 & 115.7 & 222.2 & 328.9 \\
\hline 2012 & 224.6 & 85.1 & 37.87 & 107.9 & 244.3 & 334.3 \\
\hline 2013 & 224.6 & 86.0 & 38.32 & 103.7 & 227.9 & 341.9 \\
\hline 2014 & 219.7 & 80.4 & 36.59 & 101 & 225.1 & 334.7 \\
\hline 2015 & 218.3 & 82.9 & 37.99 & 107.5 & 222.1 & 331.6 \\
\hline 2016 & 226.5 & 84.0 & 37.1 & 100.7 & 235.4 & 334.5 \\
\hline 2017 & 222.6 & 81.9 & 36.81 & 109.9 & 224.8 & 341.5 \\
\hline 2018 & 219.1 & 80.2 & 36.6 & 114.3 & 231.9 & 327.5 \\
\hline
\end{tabular}

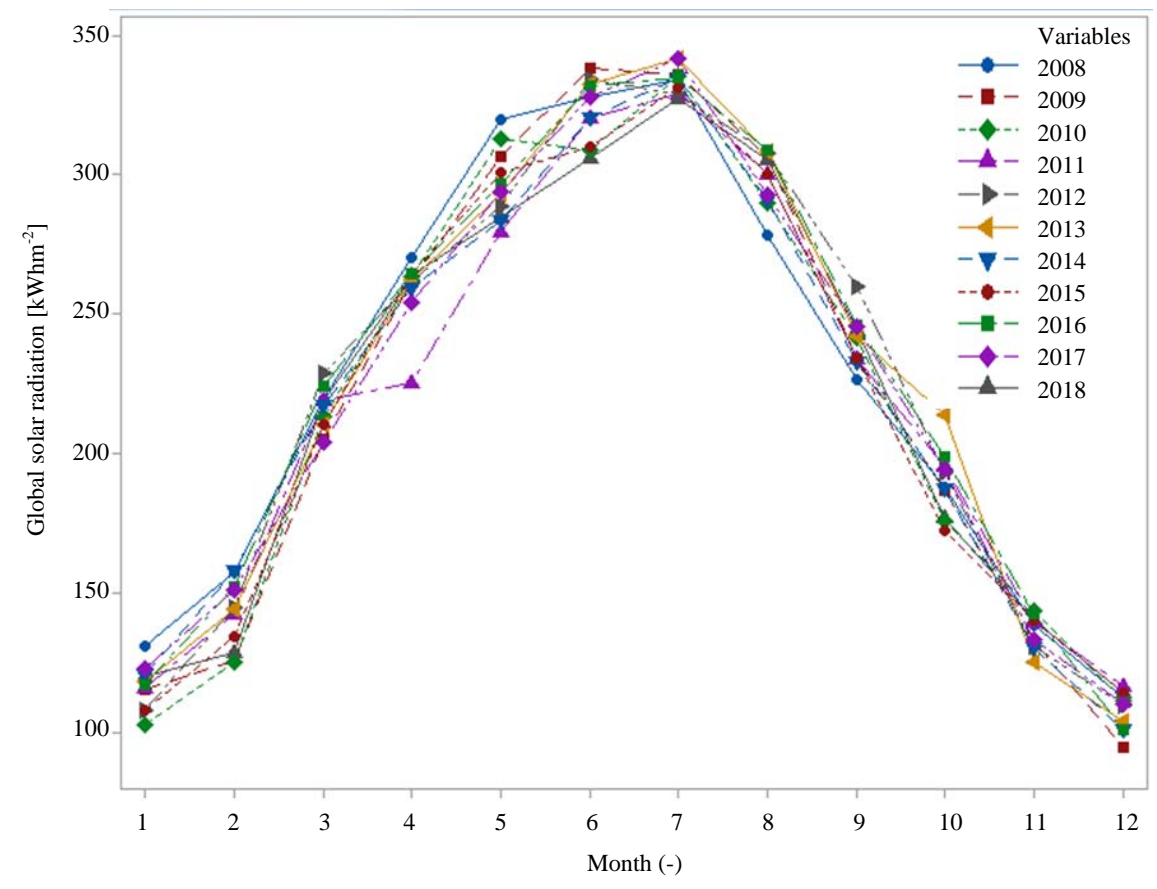

Fig. 4: Monthly mean global solar radiation in North Nicosia

summary of the monthly meteorological parameter from the years 2008-2018. It is found that the maximum and minimum mean temperature values are recorded in 2018 and 2011 with a value of 20.18 and 18.87, respectively. In addition, it is observed that the highest maximum temperature is found to be 39.72 in 2010 while the lowest minimum temperature is achieved in 2008 with a value of 1.69 . Furthermore, it is noticed sunshine duration in North Nicosia is varied from 7.94-12.967 h/day with an average of $8.4 \mathrm{~h} /$ day. Additionally, it is found that global solar radiation data are within the range of $5.4-341.9 \mathrm{kWhm}^{-2}$ and the mean annual global solar radiation is found to be $2437.52 \mathrm{kWhm}^{-2}$. The variation of monthly mean global solar radiation is illustrated in Fig. 4. It is found that the maximum monthly global solar radiation of $341.85 \mathrm{kWhm}^{-2}$ is recorded on July 2013 and the minimum value of $94.37 \mathrm{kWhm}^{-2}$ is achieved in December, 2009.

Generally, the relative humidity and air temperature are most important of meteorological parameters for the operating safety conditions of the PV module are satisfied or not. The monthly mean values of relative humidity obtained for North Nicosia is depicted in Fig. 5. It is 


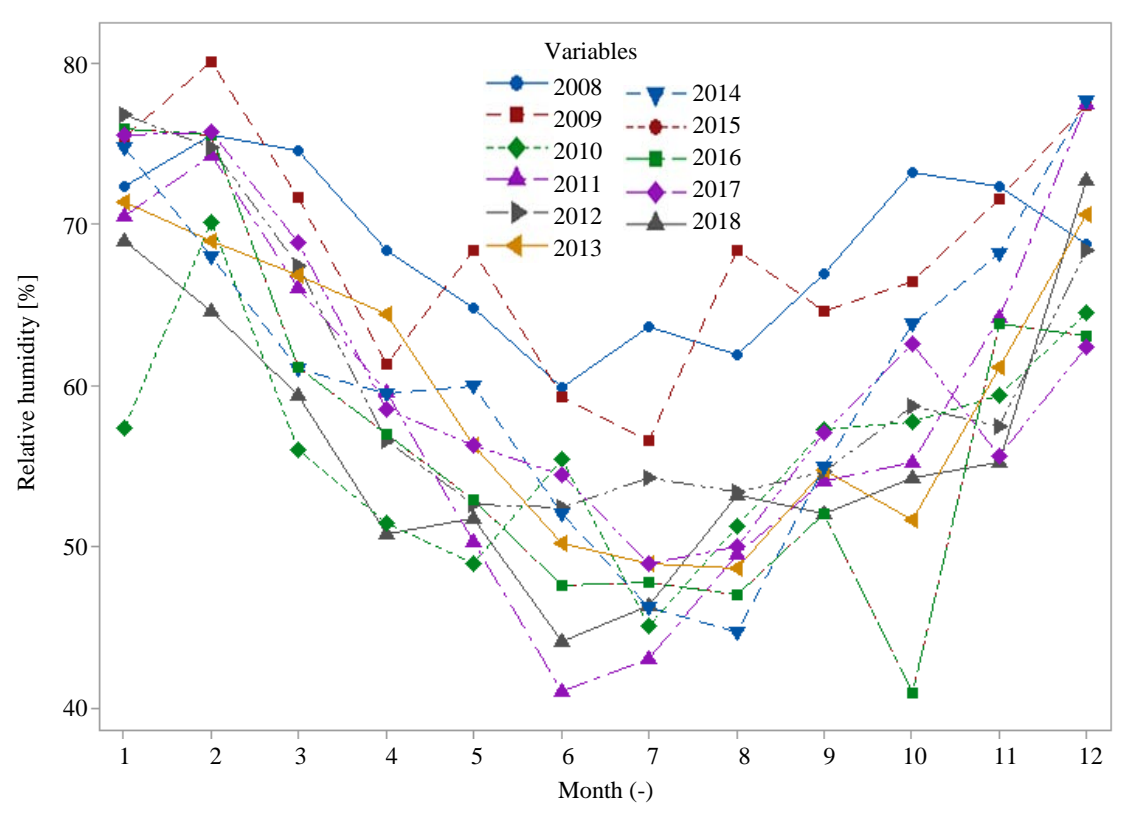

Fig. 5: Monthly mean relative humidity in North Nicosia

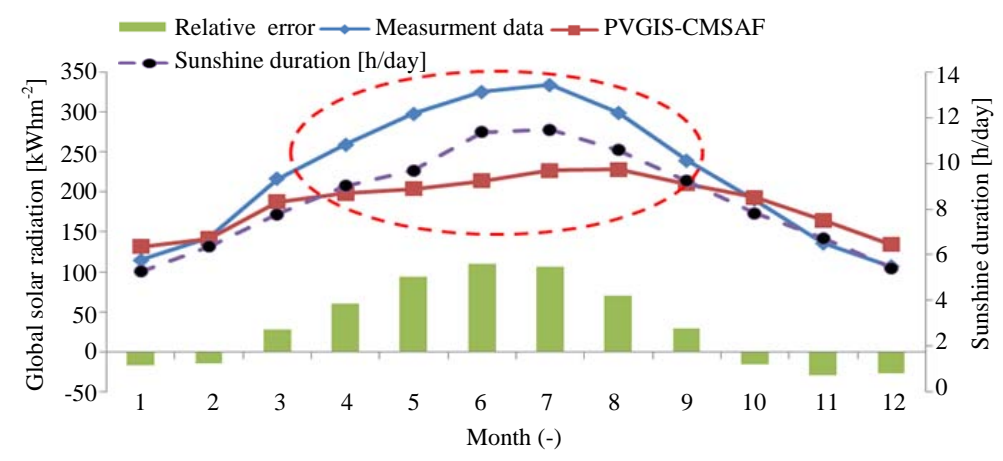

Fig. 6: Global solar radiation for North Nicosia in the year 2015 using meteorology data measured and PVGIS

observed that the minimum and maximum relative humidity values are obtained in October, 2016 and February, 2009, respectively.

Based on the measurement data, the annual mean air temperature in North Nicosia is 19.5, the mean relative humidity is $60.4 \%$ and the total sunshine duration and annual global solar radiation are 100 and $2437.52 \mathrm{kWhm}^{-2}$, respectively.

Global solar radiation for North Nicosia using meteorology data measured and PVGIS: In the current study, the measurement data were collected from 2008-2018 in North Nicosia. North Nicosia is the capital city of Northern Cyprus and located at the latitude of $35.180^{\circ} \mathrm{N}$ and a longitude of $33.374^{\circ} \mathrm{E}$. Figure 6 shows the mean monthly value of global solar radiation for North Nicosia during the period of 2008-2016. It is observed that relative error during Spring and Summer season is within the range of $61.09-110.93 \mathrm{kWhm}^{-2}$, this is due to the highest number of bright sunshine attainment in these seasons as shown in Fig. 6. Moreover, Fig. 7 shows the variation of averaged temperature during the period of 2008-2016. It is noticed that a good agreement between the measured temperature (actual data) and simulated data obtained from PVGIS Software. It is also found that the relative error is varied from -4.21-2.12.

\section{Solar potential in NEU Grand Library}

Variations in solar radiation and energy generation for BIPV system: This section is aimed to show how much solar energy will be absorbed by the surfaces of the building which can be helpful, especially when PV systems are used in the building in the shapes of solar panels to convert sunlight into electricity. Therefore, the 


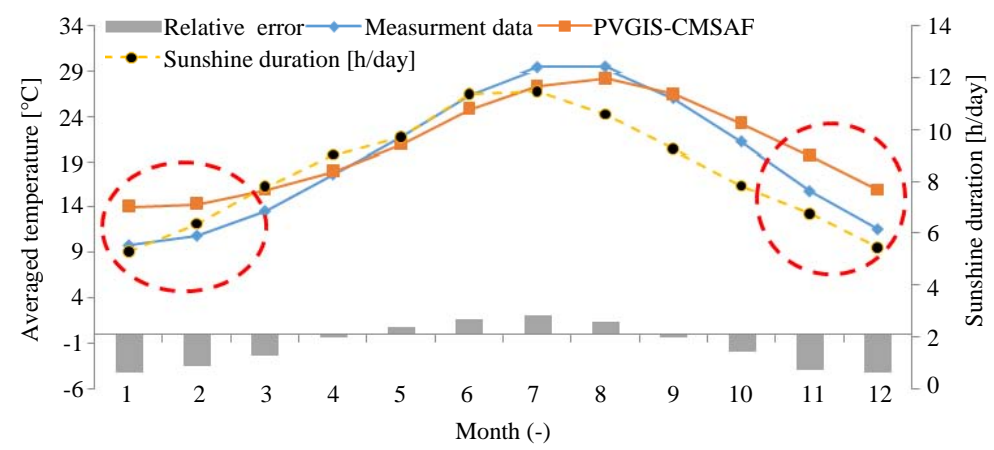

Fig. 7: Averaged temperature for North Nicosia in the year 2015 using meteorology data measured and PVGIS
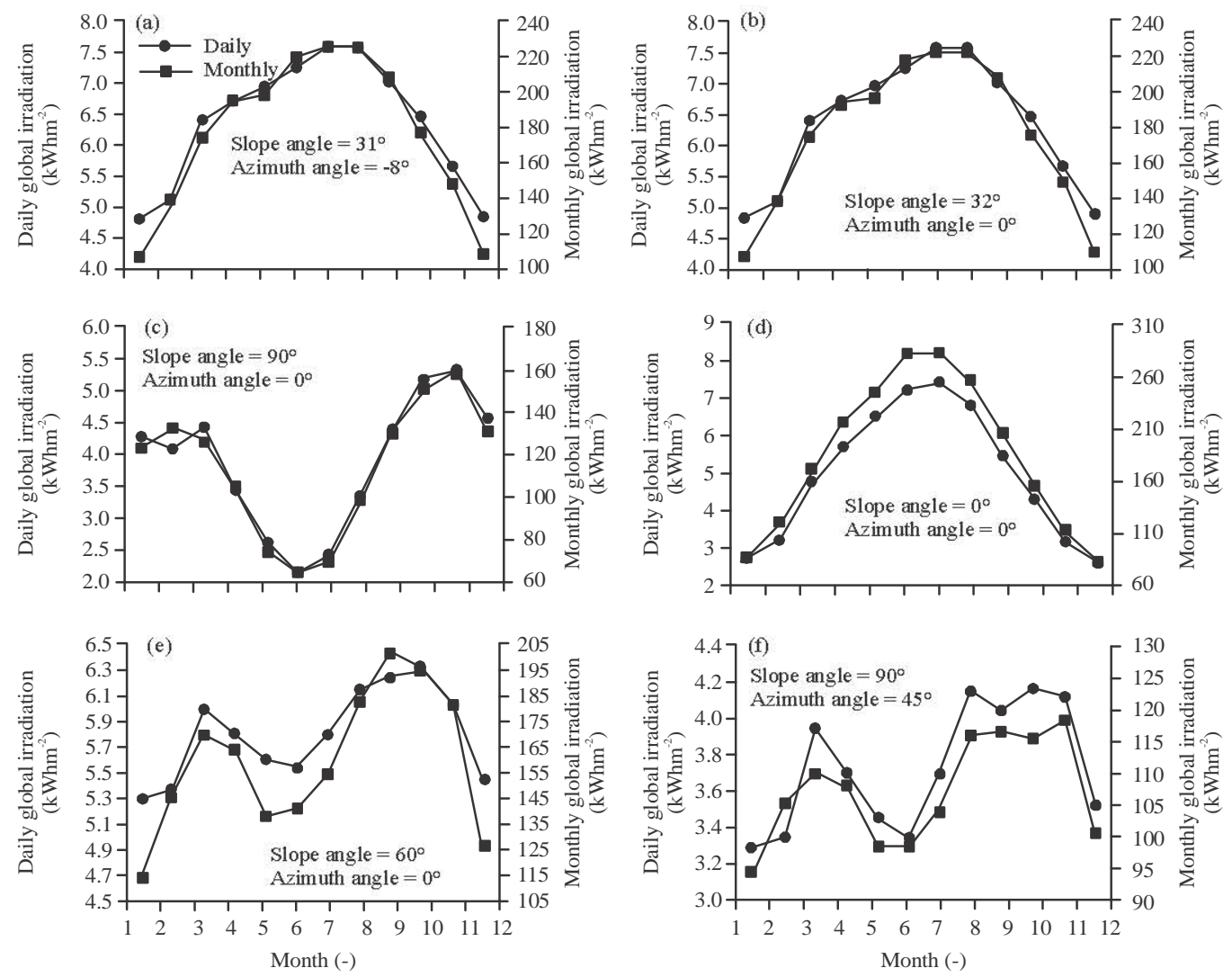

Fig. 8(a-f): Global irradiation per square meter received by the modules of the given system

slope and azimuth angles are varied based on the orientation of the walls and roof. The mean daily and monthly global irradiation with various slope and azimuth angles and PV technologies simulation tool are shown in Fig. 8. In addition, the average daily and monthly energy productions from the proposed system using crystalline, CIS, CdTe technology are shown in Fig. 9 and 10, respectively.

Considering the PVGIS simulation tool, it is found that the optimum slope and azimuth angles are
31 and $-8^{\circ}$, respectively. According to these angles, it is observed that the monthly maximum and minimum solar radiation are achieved in July and January with a value of 235 and $130 \mathrm{kWhm}^{-2}$, respectively. Furthermore, the maximum possible energy recorded in July, i.e., $4940 \mathrm{kWh} /$ year with crystalline technology, $5240 \mathrm{kWh} / \mathrm{year}$ with CIS and $5580 \mathrm{kWh} /$ year with CdTe technology under same climatic condition. The analysis indicates that the BIPV system with CdTe technology is observed to perform better than 

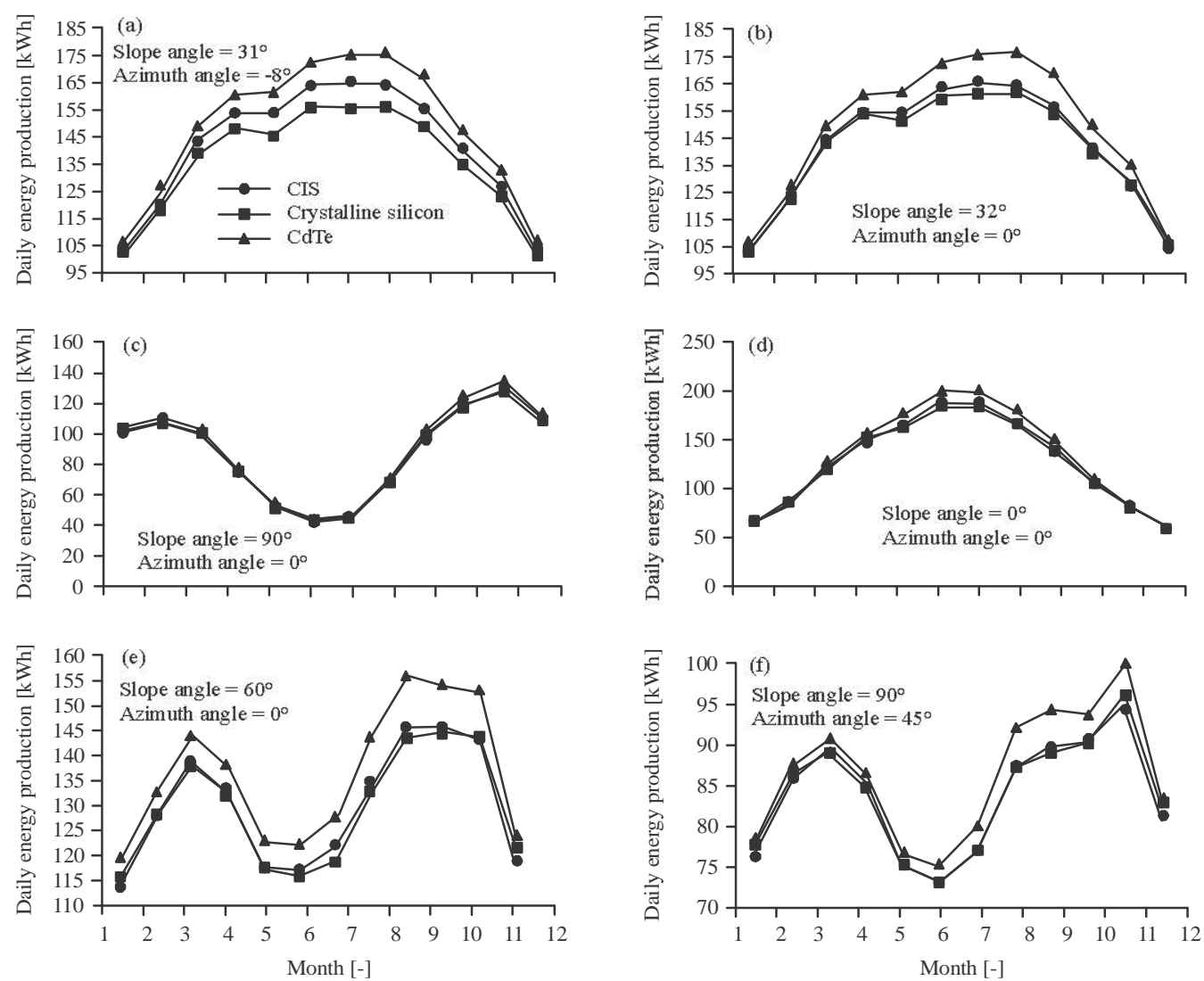

Fig. 9(a-f): Average daily energy production from the given system

Table 3: Solar radiation and energy generation with various angles and technologies

\begin{tabular}{|c|c|c|c|c|c|}
\hline PV technology/Slope angle [ $\left.{ }^{\circ}\right]$ & Azimuth angle $\left[{ }^{\circ}\right]$ & $\mathrm{Ed}[\mathrm{kWh} / \mathrm{d}]$ & Em [kWh] & $\mathrm{Hd}\left[\mathrm{kWh} / \mathrm{m}^{2} \mathrm{~d}\right]$ & $\mathrm{Hm}[\mathrm{kV}$ \\
\hline \multicolumn{6}{|l|}{ Crystalline silicon } \\
\hline 31 & -8 & 138 & 4200 & 6.21 & 1 \\
\hline 32 & 0 & 143 & 4340 & 6.19 & 18 \\
\hline 90 & 0 & 87 & 2650 & 3.79 & 11 \\
\hline 0 & 0 & 126 & 3840 & 5.49 & 167 \\
\hline 60 & 0 & 130 & 3940 & 5.59 & 170 \\
\hline 90 & 45 & 84.1 & 2560 & 3.65 & 111 \\
\hline \multicolumn{6}{|l|}{ CIS } \\
\hline 31 & -8 & 144 & 4380 & 6.21 & 1 \\
\hline 32 & 0 & 144 & 4370 & 6.19 & 1 \\
\hline 90 & 0 & 86.2 & 2620 & 3.79 & 1 \\
\hline 0 & 0 & 127 & 3863 & 5.48 & 167 \\
\hline 60 & 0 & 130 & 3960 & 5.59 & 1 \\
\hline 90 & 45 & 83.9 & 2550 & 3.65 & 111 \\
\hline \multicolumn{6}{|l|}{ CdTe } \\
\hline 31 & -8 & 151 & 4610 & 6.21 & 1 \\
\hline 32 & 0 & 151 & 4600 & 6.19 & 1 \\
\hline 90 & 0 & 89 & 2710 & 3.79 & 115 \\
\hline 0 & 0 & 133 & 4050 & 5.49 & 167 \\
\hline 60 & 0 & 136 & 4150 & 5.59 & 170 \\
\hline 90 & 45 & 86.6 & 2630 & 3.65 & 111 \\
\hline
\end{tabular}

Ed: Average daily energy production from the given system, Em: Average monthly energy production from the given system, Hd: Average daily sum of global irradiation per square meter received by the modules of the given system, Hm: Average monthly sum of global irradiation per square meter received by the modules of the given system

crystalline and CIS technologies with the maximum possible energy of $5580 \mathrm{kWh}$ in July and the minimum energy of $3300 \mathrm{kWh}$ in January. Moreover, Table 3 is summarized the average value of solar radiation and 
energy generation with various angles and technologies. It is noticed that the PV system with CIS technology has minimum energy production compared to crystalline technology for slope angle of $90^{\circ}$ and azimuth angle of $45^{\circ}$.

Performance analysis: The annual solar radiation and energy production were estimated based on the PVGIS

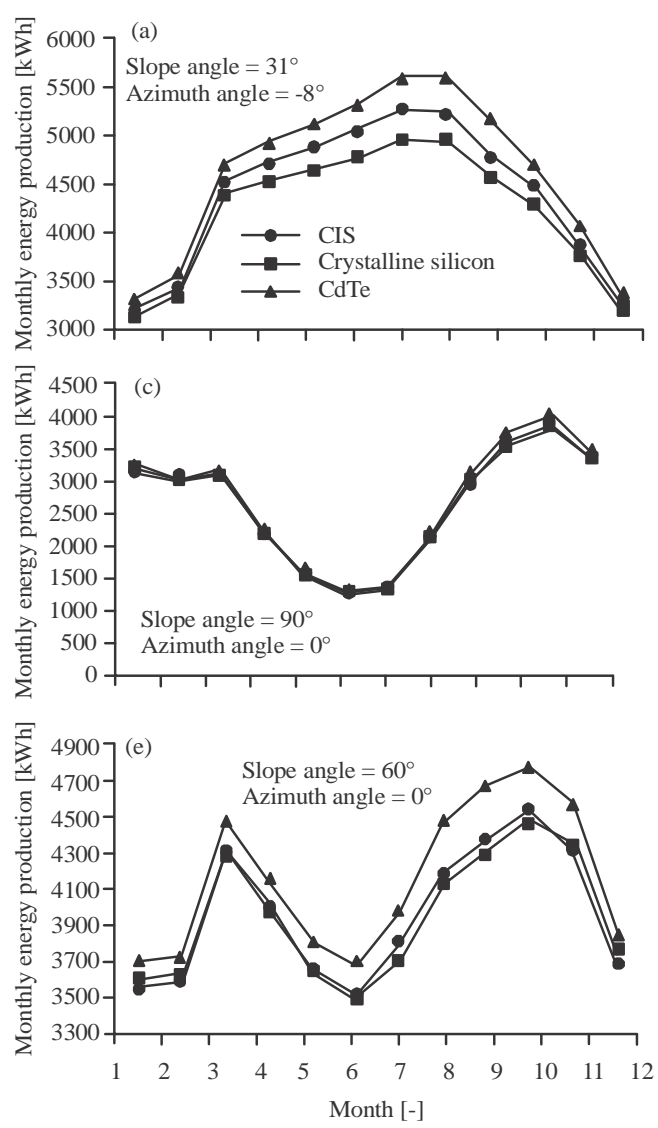

simulation tool. The quantities that used to assess the performance of BIPV system in terms of specific annual yield, annual array yield, annual reference yield and capacity factor were calculated for different PV technologies and angles as shown in Table 4. It is found that the minimum capacity factor for PV system with all PV technologies is recorded for slope angle of $90^{\circ}$ and azimuth angles of $0^{\circ}$ and $45^{\circ}$ (Table 5). Therefore, the

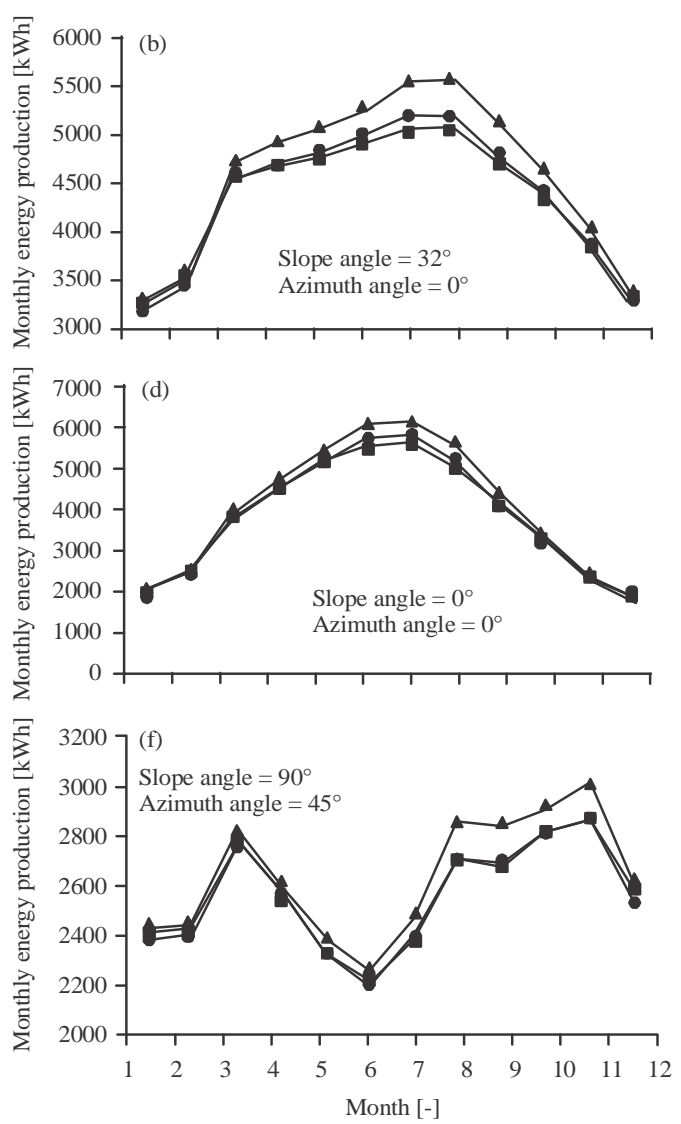

Fig. 10(a-f): Average monthly energy production from the given system

Table 4: Summary of performance parameters of BIPV system

\begin{tabular}{|c|c|c|c|c|c|c|}
\hline \multirow[b]{2}{*}{ PV technology/Parameters } & \multicolumn{6}{|c|}{ Slope and azimuth angles } \\
\hline & 31 and $-8^{\circ}$ & 32 and $0^{\circ}$ & 90 and $0^{\circ}$ & 0 and $0^{\circ}$ & 60 and $0^{\circ}$ & 90 and $45^{\circ}$ \\
\hline \multicolumn{7}{|l|}{ Crystalline silicon } \\
\hline PV system [kWp] & 30 & 30 & 30 & 30 & 30 & 30 \\
\hline Annual PV energy [kWh] & 52100 & 52100 & 31800 & 46000 & 47300 & 30700 \\
\hline Array output energy $[\mathrm{kWh} / \mathrm{d}]$ & 2260 & 2260 & 1380 & 2000 & 2040 & 1330 \\
\hline Yearly in-plane irradiation $\left[\mathrm{KWh} / \mathrm{m}^{2}\right]$ & 2454 & 2449 & 1501 & 2170 & 2210 & 1442 \\
\hline Annual mean daily irradiation in array plane $\left[\mathrm{kWhm}^{-2} \mathrm{~d}\right]$ & 6.21 & 6.19 & 3.79 & 5.49 & 5.59 & 3.65 \\
\hline Specific annual yield $[\mathrm{kWh} / \mathrm{kWp}]$ & 1737 & 1737 & 1060 & 1533 & 1577 & 1023 \\
\hline Annual array yield [kWh/kWp.d] & 75 & 75 & 46 & 67 & 68 & 44 \\
\hline Annual reference yield [kWh/kWpd] & 6.21 & 6.19 & 3.79 & 5.49 & 5.59 & 3.65 \\
\hline Capacity factor [\%] & 19.82 & 19.82 & 12.10 & 17.50 & 18.00 & 11.68 \\
\hline \multicolumn{7}{|l|}{ CIS } \\
\hline PV system [kWp] & 30 & 30 & 30 & 30 & 30 & 30 \\
\hline Annual PV energy [kWh] & 52800 & 52400 & 31500 & 46400 & 47500 & 30600 \\
\hline Array output energy [kWh/d] & 2260 & 2260 & 1380 & 2000 & 2040 & 1330 \\
\hline
\end{tabular}


J. Eng. Applied Sci., 15 (4): 1027-1042, 2020

Table 4: Continue

\begin{tabular}{|c|c|c|c|c|c|c|}
\hline \multirow[b]{2}{*}{ PV technology/Parameters } & \multicolumn{6}{|c|}{ Slope and azimuth angles } \\
\hline & 31 and $-8^{\circ}$ & 32 and $0^{\circ}$ & 90 and $0^{\circ}$ & 0 and $0^{\circ}$ & 60 and $0^{\circ}$ & 90 and $45^{\circ}$ \\
\hline Yearly in-plane irradiation $\left[\mathrm{KWhm}^{-2}\right]$ & 2454 & 2449 & 1501 & 2169.91667 & 2210 & 1442 \\
\hline Annual mean daily irradiation in array plane $\left[\mathrm{kWhm}^{-2} \mathrm{~d}\right]$ & 6.21 & 6.19 & 3.79 & 5.49 & 5.59 & 3.65 \\
\hline Specific annual yield $[\mathrm{kWh} / \mathrm{kWp}]$ & 1760 & 1747 & 1050 & 1547 & 1583 & 1020 \\
\hline Annual array yield [KWh/kWpd] & 75 & 75 & 46 & 67 & 68 & 44 \\
\hline Annual reference yield [kWh/kWpd] & 6.21 & 6.19 & 3.79 & 5.49 & 5.59 & 3.65 \\
\hline Capacity factor [\%] & 20.09 & 19.94 & 11.99 & 17.66 & 18.07 & 11.64 \\
\hline \multicolumn{7}{|l|}{ CdTe } \\
\hline PV system [kWp] & 30 & 30 & 30 & 30 & 30 & 30 \\
\hline Annual PV energy [kWh] & 55300 & 55200 & 32500 & 48600 & 49800 & 31600 \\
\hline Array output energy $[\mathrm{kWh} / \mathrm{d}]$ & 2260 & 2260 & 1380 & 2000 & 2040 & 1330 \\
\hline Yearly in plane irradiation $\left[\mathrm{KWhm}^{-2}\right]$ & 2455 & 2449 & 1501 & 2170 & 2210 & 1442 \\
\hline Annual mean daily irradiation in array plane $\left[\mathrm{kWhm}^{-2} \mathrm{~d}\right]$ & 6.21 & 6.19 & 3.79 & 5.49 & 5.59 & 3.65 \\
\hline Specific annual yield $[\mathrm{kWh} / \mathrm{kWp}]$ & 1843 & 1840 & 1083 & 1620 & 1660 & 1053 \\
\hline Annual array yield [KWh $/ \mathrm{kWp} . \mathrm{d}]$ & 75 & 75 & 46 & 67 & 68 & 44 \\
\hline Annual reference yield [kWh/kWpd] & 6.21 & 6.19 & 3.79 & 5.49 & 5.59 & 3.65 \\
\hline Capacity factor $[\%]$ & 21.04 & 21.00 & 12.37 & 18.49 & 18.95 & 12.02 \\
\hline
\end{tabular}

Table 5: Annual performance comparison and losses of BAPV and BIPV system

\begin{tabular}{|c|c|c|c|c|c|c|}
\hline \multirow[b]{2}{*}{ Type PV technology/Parameters } & \multicolumn{6}{|c|}{ Slope and azimuth angles } \\
\hline & 31 and $-8^{\circ}$ & 32 and $0^{\circ}$ & 90 and $0^{\circ}$ & 0 and $0^{\circ}$ & 60 and $0^{\circ}$ & 90 and $45^{\circ}$ \\
\hline \multicolumn{7}{|l|}{ BAPV (Crystalline silicon) } \\
\hline PV energy production [kWh/year] & 54500 & 54400 & 32700 & 47900 & 49300 & 31700 \\
\hline In-plane irradiation $\left[\mathrm{kWh} / \mathrm{m}^{2} /\right.$ year] & 2260 & 2260 & 1380 & 2000 & 2040 & 1330 \\
\hline Angle of incidence losses [\%] & -2.7 & -2.6 & -6.3 & -3.4 & -3.2 & -4.5 \\
\hline Spectral effects losses [\%] & 0.4 & 0.4 & 0.7 & 0.2 & 0.5 & 0.5 \\
\hline Temperature and low irradiance losses [\%] & -8.8 & -8.7 & -7.2 & -8.5 & -8.1 & -8.1 \\
\hline Total loss [\%] & -19.8 & -19.7 & -21.1 & -20.3 & -19.5 & -20.6 \\
\hline Capacity factor [\%] & 20.74 & 20.70 & 12.44 & 18.23 & 18.76 & 12.06 \\
\hline Performance ratio [\%] & 80.38 & 80.24 & 78.99 & 79.83 & 80.56 & 79.45 \\
\hline \multicolumn{7}{|l|}{ BIPV (Crystalline silicon) } \\
\hline PV energy production [kWh/year] & 52100 & 52100 & 31800 & 46000 & 47300 & 30700 \\
\hline In-plane irradiation $\left[\mathrm{kWh} / \mathrm{m}^{2} /\right.$ year $]$ & 2260 & 2260 & 1380 & 2000 & 2040 & 1330 \\
\hline Angle of incidence losses [\%] & -2.7 & -2.6 & -6.3 & -3.4 & -3.2 & -4.5 \\
\hline Spectral effects losses [\%] & 0.4 & 0.4 & 0.7 & 0.3 & 0.5 & 0.5 \\
\hline Temperature and low irradiance losses [\%] & -12.8 & -12.7 & -10 & -12.1 & -11.8 & -11 \\
\hline Total loss [\%] & -23.3 & -23.2 & -23.5 & -23.4 & -22.8 & -23.1 \\
\hline Capacity factor [\%] & 19.82 & 19.82 & 12.10 & 17.50 & 18.00 & 11.68 \\
\hline Performance ratio [\%] & 76.84 & 76.84 & 76.81 & 76.67 & 77.29 & 76.94 \\
\hline \multicolumn{7}{|l|}{ BAPV (CIS) } \\
\hline PV energy production $[\mathrm{kWh} /$ year] & 53800 & 53700 & 32000 & 47400 & 48500 & 31200 \\
\hline In-plane irradiation $\left[\mathrm{kWhm}^{-2} /\right.$ year] & 2260 & 2260 & 1380 & 2000 & 2040 & 1330 \\
\hline Angle of incidence losses [\%] & -2.7 & -2.6 & -6.3 & -3.4 & -3.2 & -4.5 \\
\hline Spectral effects losses [\%] & - & - & - & - & - & - \\
\hline Temperature and low irradiance losses [\%] & -9.6 & -9.6 & -8.7 & -9.3 & -9 & -9.2 \\
\hline Total loss [\%] & -20.8 & -20.8 & -22.9 & -21.2 & -20.7 & -21.9 \\
\hline Capacity factor [\%] & 20.47 & 20.43 & 12.18 & 18.04 & 18.46 & 11.87 \\
\hline Performance ratio [\%] & 79.35 & 79.20 & 77.29 & 79.00 & 79.25 & 78.20 \\
\hline \multicolumn{7}{|l|}{ BIPV (CIS) } \\
\hline PV energy production [kWh/year] & 52800 & 52400 & 31500 & 46400 & 47500 & 30600 \\
\hline In-plane irradiation $\left[\mathrm{kWhm}^{-2} /\right.$ year] & 2260 & 2260 & 1380 & 2000 & 2040 & 1330 \\
\hline Angle of incidence losses [\%] & -2.7 & -2.6 & -6.3 & -3.4 & -3.2 & -4.5 \\
\hline Spectral effects losses [\%] & - & - & - & - & - & - \\
\hline Temperature and low irradiance losses [\%] & -11.8 & -11.7 & -10.2 & -11.3 & -11 & -10.8 \\
\hline Total loss [\%] & -22.7 & -22.6 & -24.2 & -22.8 & -22.5 & -23.3 \\
\hline Capacity factor [\%] & 20.09 & 19.94 & 11.99 & 17.66 & 18.07 & 11.64 \\
\hline Performance ratio [\%] & 77.88 & 77.29 & 76.09 & 77.33 & 77.61 & 76.69 \\
\hline \multicolumn{7}{|l|}{ BAPV (CdTe) } \\
\hline PV energy production [kWh/year] & 56300 & 56200 & 32900 & 49300 & 50600 & 32000 \\
\hline In-plane irradiation $\left[\mathrm{kWhm}^{-2} /\right.$ year] & 2260 & 2260 & 1380 & 2000 & 2040 & 1330 \\
\hline Angle of incidence losses [\%] & -2.7 & -2.6 & -6.3 & -3.4 & -3.2 & -4.5 \\
\hline Spectral effects losses [\%] & 0.8 & 0.8 & 0.9 & 0.7 & 0.8 & 0.8 \\
\hline Temperature and low irradiance losses [\%] & -6.2 & -6.2 & -7 & -6.3 & -6 & -7.5 \\
\hline
\end{tabular}


Table 5: Continue

\begin{tabular}{|c|c|c|c|c|c|c|}
\hline \multirow[b]{2}{*}{ Type PV technology/Parameters } & \multicolumn{6}{|c|}{ Slope and azimuth angles } \\
\hline & 31 and $-8^{\circ}$ & 32 and $0^{\circ}$ & 90 and $0^{\circ}$ & 0 and $0^{\circ}$ & 60 and $0^{\circ}$ & 90 and $45^{\circ}$ \\
\hline Total loss [\%] & -17.2 & -17.1 & -20.8 & -17.9 & -17.4 & -19.8 \\
\hline Capacity factor [\%] & 21.42 & 21.39 & 12.52 & 18.76 & 19.25 & 12.18 \\
\hline Performance ratio [\%] & 83.04 & 82.89 & 79.47 & 82.17 & 82.68 & 80.20 \\
\hline \multicolumn{7}{|l|}{ BIPV (CdTe) } \\
\hline PV energy production $[\mathrm{kWh} /$ year $]$ & 55300 & 55200 & 32500 & 48600 & 49800 & 31600 \\
\hline In-plane irradiation [kWhm ${ }^{-2} /$ year] & 2260 & 2260 & 1380 & 2000 & 2040 & 1330 \\
\hline Angle of incidence losses [\%] & -2.7 & -2.6 & -6.3 & -3.4 & -3.2 & -4.5 \\
\hline Spectral effects losses [\%] & 0.8 & 0.8 & 0.9 & 0.7 & 0.8 & 0.8 \\
\hline Temperature and low irradiance losses [\%] & -7.8 & -7.8 & -8 & -7.7 & -7.4 & -8.7 \\
\hline Total loss [\%] & -18.6 & -18.6 & -21.8 & -19.2 & -18.7 & -20.8 \\
\hline Capacity factor [\%] & 21.04 & 21.00 & 12.37 & 18.49 & 18.95 & 12.02 \\
\hline Performance ratio [\%] & 81.56 & 81.42 & 78.50 & 81.00 & 81.37 & 79.20 \\
\hline
\end{tabular}

vertically mounted BIPV system will be neglected, since, it will be produced minimum energy production. Moreover, the results show that the best slope angle is $32^{\circ}$ with an annual energy production of $56400 \mathrm{kWh} /$ year for PV system with crystalline silicon. In addition, the best slope angle to obtain the maximum annual energy production is found to be $56890 \mathrm{kWh} /$ year and $59900 \mathrm{kWh} /$ year for PV system with CIS and CdTe technologies, respectively is $31^{\circ}$.

Comparing the performance energy of BAPV and BIPV: Type of the PV technology used, system losses and loss due to the angle of incidence, loss due to temperature and irradiance are the most important parameters that should be considered during the estimation of the energy performance of PV system. Therefore, system losses and the loss due to the angle of incidence, loss due to temperature for different angles (slope and azimuth angles) have been calculated using PVGIS simulation tool and listed in Table 5. In addition, the capacity factor and performance ratio of each proposed configuration are calculated using Eq. 4 and 5 and presented in Table 5. It concluded that among the proposed two systems, BAPV system performs better than BIPV and technology wise CdTe performs better than CIS and crystalline.

\section{CONCLUSION}

The objective of this paper was to analyze the performance of $30 \mathrm{kWp}$ grid-connected BIPV and BAPV with various angles (slop and azimuth angles) and three PV technologies using PVGIS simulation tool. From this analysis, the following conclusion were drawn:

Based on the measurement data, the annual mean air temperature in North Nicosia is 19.5 , the mean relative humidity is $60.4 \%$ and the total sunshine duration and annual global solar radiation are $100.7 \mathrm{~h} /$ day and $2437.52 \mathrm{kWhm}^{-2}$, respectively.

It is observed that relative error between the actual data and simulated data during spring and summer season is within the range of $61.09-110.93 \mathrm{kWhm}^{-2}$, this is due to the highest number of bright sunshine attainment in these seasons.

It is noticed that PV system with CIS technology has minimum energy production compared to crystalline technology for slope angle of $90^{\circ}$ and azimuth angle of $45^{\circ}$. The total losses in a CdTe technology were observed to be lower than CIS and c-Si technology. Based on these outcomes, it concluded that CdTe is the best PV technology compared to most widely used PV technologies (c-Si) and the existing buildings can be turned into power stations with this approach of BIPV and BAPV.

\section{ACKNOWLEDGEMENT}

The researchers would like to thank the Faculty of Civil and Environment Engineering, especially, the Civil Engineering Department at Near East University for their support and encouragement.

\section{REFERENCES}

Argungu, G.M. and K.A. Dabai, 2017. Application of linear models for estimation of global solar radiation using available meteorological parameters for Sokoto, Nigeria. Int. J. Adv. Sci. Res. Eng., 3: $76-83$.

Assamidanov, A., N. Nogerbek and L. Rojas-Solorzano, 2018. Technical and Economic Prefeasibility Analysis of Residential Solar PV System in South Kazakhstan. In: Exergy for a Better Environment and Improved Sustainability 2, Aloui, F. and I. Dincer (Eds.). Springer, Cham, Switzerland, ISBN: 978-3-319-62574-4, pp: 783-792.

Assi, A., K. Al Kathairi and M. Jama, 2009. Building Integrated PhotoVoltaic (BIPV) in the United Arab Emirates-Tool and case study. Proceedings of the 2009 5th IEEE International GCC Conference \& Exhibition, March 17-19, 2009, IEEE, Kuwait City, Kuwait, pp: 1-5. 
Ayompe, L.M., A. Duffy, S.J. McCormack and M. Conlon, 2011. Measured performance of a $1.72 \mathrm{~kW}$ rooftop grid connected photovoltaic system in Ireland. Energy Convers. Manage., 52: 816-825.

Bakos, G.C., M. Soursos and N.F. Tsagas, 2003. Technoeconomic assessment of a building-integrated PV system for electrical energy saving in residential sector. Energy Build., 35: 757-762.

Belkilani, K., A.B. Othman and M. Besbes, 2018. Assessment of global solar radiation to examine the best locations to install a PV system in Tunisia. Applied Phys. A., Vol. 124, 10.1007/s00339-0181551-3

Bhatia, S.C., 2014. Advanced Renewable Energy Systems. Woodhead, New Delhi, India, ISBN: 9781782422730, Pages: 775 .

Bocca, A., L. Bottaccioli, E. Chiavazzo, M. Fasano, A. Macii and P. Asinari, 2016. Estimating photovoltaic energy potential from a minimal set of randomly sampled data. Renewable Energy, 97: 457-467.

Bonomo, P., F. Frontini, P. de Berardinis and I. Donsante, 2017. BIPV: Building envelope solutions in a multi-criteria approach: A method for assessing life-cycle costs in the early design phase. Adv. Build. Energy Res., 11: 104-129.

Chakraborty, S., R. Hosain, T. Rahman and A.F. Rabbi, 2014. Economic and environmental assessment of a $1 \mathrm{MW}$ grid connected rooftop solar PV system for energy efficient building in Bangladesh. Proceedings of the International Congress on Energy Efficiency and Energy Related Materials (ENEFM'13), October 9-12, 2013, Springer, Antalya, Turkey, pp: 345-352.

Chang, B. and K. Starcher, 2019. Evaluation of wind and solar energy investments in Texas. Renewable Energy, 132: 1348-1359.

Chateau, B. and B. Lapillonne, 1982. The MEDEE Approach: Analysis and Long-Term Forecasting of Final Energy Demand of a Country. In: Energy Modelling Studies and Conservation, Stuart, S. (Ed.). Elsevier, Amsterdam, Netherlands, ISBN: 9781483147031, pp: 57-67.

Chel, A. and G. Kaushik, 2018. Renewable energy technologies for sustainable development of energy efficient building. Alexandria Eng. J., 57: 655-669.

DPMMFA., 2019. Greatest renewable energy project of North Cyprus at UKU. Deputy Prime Minister and Ministry Foreign Affairs TRNC., Turkey. https://mfa.gov.ct.tr/greatest-renewable-energyproject-north-cyprus-uku/

Debbarma, M., K. Sudhakar and P. Baredar, 2016. Comparison of BIPV and BIPVT: A review. Resour.-Efficient Technol., 3: 263-271.
Dondariya, C., D. Porwal, A. Awasthi, A.K. Shukla, K. Sudhakar, M.M. SR and A. Bhimte, 2018. Performance simulation of grid-connected rooftop solar PV system for small households: A case study of Ujjain, India. Energy Rep., 4: 546-553.

EWEA., 2015. Wind Energy-The Facts: A Guide to the Technology, Economics and Future of Wind Power. Routledge, Abingdon, UK., ISBN: 9781138881266, Pages: 592.

Enongene, K.E., F.H. Abanda, I.J.J. Otene, S.I. Obi and C. Okafor, 2019. The potential of solar photovoltaic systems for residential homes in Lagos city of Nigeria. J. Environ. Manage., 244: 247-256.

Fina, B., H. Auer and W. Friedl, 2019. Profitability of active retrofitting of multi-apartment buildings: Building-attached/integrated photovoltaics with special consideration of different heating systems. Energy Build., 190: 86-102.

Fokaides, P.A. and A. Kylili, 2014. Towards grid parity in insular energy systems: The case of PhotoVoltaics (PV) in Cyprus. Energy Policy, 65: 223-228.

Fouad, M.M., L.A. Shihata and A.H. Mohamed, 2019. Modeling and analysis of Building Attached Photovoltaic Integrated Shading Systems (BAPVIS) aiming for zero energy buildings in hot regions. J. Build. Eng., 21: 18-27.

Halbe, A., J. Novak, K. Sharpe, G. Housser and P. Haldars, 2014. Evaluation of mounting mechanisms for the installation of lightweight PV systems on commercial rooftops. Proceedings of the 2014 IEEE 40th International Conference on Photovoltaic Specialist (PVSC'14), June 8-13, 2014, IEEE, Denver, Colorado, USA., pp: 3539-3542.

Harkouss, F., F. Fardoun and P.H. Biwole, 2019. Optimal design of renewable energy solution sets for net zero energy buildings. Energy, 179: 1155-1175.

Hassaine, L. and A. Mraoui, 2017. Potential of Solar Electricity for Grid-Connected Systems in Algeria. In: Mediterranean Green Buildings \& Renewable Energy, Sayigh, A. (Ed.). Springer, Cham, Switzerland, ISBN: 978-3-319-30745-9, pp: 561-573.

Heinstein, P., C. Ballif and L.E. Perret-Aebi, 2013. Building Integrated PhotoVoltaics (BIPV): Review, potentials, barriers and myths. Green, 3: 125-156.

Henemann, A., 2008. BIPV: Built-in solar energy. Renewable Energy Focus, 9: 14-19.

Hossain, M.F., 2019. Sustainable technology for energy and environmental benign building design. J. Buil. Eng., 22: 130-139.

Huld, T., 2017. PVMAPS: Software tools and data for the estimation of solar radiation and photovoltaic module performance over large geographical areas. Solar Energy, 142: 171-181. 
Huovila, P., 2007. Buildings and Climate Change: Status, Challenges and Opportunities. United Nations Environment Programme, Paris, France, ISBN: 978-92-807-2795-1, Pages: 76.

Imenes, A.G., 2016. Performance of BIPV and BAPV installations in Norway. Proceedings of the 2016 IEEE 43rd International Conference on Photovoltaic Specialists (PVSC), June 5-10, 2016, IEEE, Portland, Oregon, USA., pp: 3147-3152.

Kassem, Y. and H. Gokcekus, 2018. GHG emissions and energy performance of $1 \mathrm{mw}$ grid-connected solar PV plant at Lefke in Northern Cyprus: Case study. Disaster Sci. Eng., 4: 90-98.

Kassem, Y., H. Gokcekus and H. Camur, 2018. Economic assessment of renewable power generation based on wind speed and solar radiation in urban regions. Global J. Environ. Sci. Manage., 4: 465-482.

Keoleian, G.A. and G.M. Lewis, 2003. Modeling the life cycle energy and environmental performance of amorphous silicon BIPV roofing in the US. Renewable Energy, 28: 271-293.

Kumar, N.M., K. Sudhakar and M. Samykano, 2019a. Performance comparison of BAPV and BIPV systems with c-Si, CIS and $\mathrm{CdTe}$ photovoltaic technologies under tropical weather conditions. Case Stud. Therm. Eng., Vol. 13, 10.1016/ j.csite. 2018.100374

Kumar, N.M., K. Sudhakar and M. Samykano, 2019 b. Techno-economic analysis of $1 \mathrm{MWp}$ grid connected solar PV plant in Malaysia. Int. J. Ambient Energy, 40: 434-443.

Kumar, N.M., M.R. Kumar, P.R. Rejoice and M. Mathew, 2017. Performance analysis of $100 \mathrm{kWp}$ grid connected Si-poly photovoltaic system using PVsyst simulation tool. Energy Procedia, 117: 180-189.

Lee, J.B., J.W. Park, J.H. Yoon, N.C. Baek, D.K. Kim and U.C. Shin, 2014. An empirical study of performance characteristics of BIPV (Building Integrated Photovoltaic) system for the realization of zero energy building. Energy, 66: 25-34.

Li, D.H.W., S.K.H. Chow and E.W.M. Lee, 2013. An analysis of a medium size grid-connected Building Integrated PhotoVoltaic (BIPV) system using measured data. Energy Build., 60: 383-387.

Li, L. and B.P. Loo, 2014. Alternative and transitional energy sources for urban transportation. Curr. Sustainable Renewable Energy Rep., 1: 19-26.

Liu, J., X. Chen, S. Cao and H. Yang, 2019a. Overview on hybrid solar photovoltaic-electrical energy storage technologies for power supply to buildings. Energy Convers. Manage., 187: 103-121.
Liu, Z., Y. Liu, B.J. He, W. Xu, G. Jin and X. Zhang, 2019b. Application and suitability analysis of the key technologies in nearly zero energy buildings in China. Renewable Sustainable Energy Rev., 101: 329-345.

Maltini, F. and R. Minder, 2015. The Serhatkoy Photovoltaic Power Plant and the Future of Renewable Energy on the Turkish Republic of Northern Cyprus: Integrating Solar Photovoltaic and Wind Farms into Electricity Transmission and Distribution Networks. In: Eco-Friendly Innovation in Electricity Transmission and Distribution Networks, Bessede, J.L. (Ed.). WoodheadPublishing, Cambridge, UK., pp: 377-402.

Mohammadi, K., M. Naderi and M. Saghafifar, 2018. Economic feasibility of developing grid-connected photovoltaic plants in the southern coast of Iran. Energy, 156: 17-31.

Nassar, Y.F. and S.Y. Alsadi, 2019. Assessment of solar energy potential in Gaza Strip-Palestine. Sustainable Energy Technol. Assess., 31: 318-328.

Ng, P.K. and N. Mithraratne, 2014. Lifetime performance of semi-transparent Building-Integrated PhotoVoltaic (BIPV) glazing systems in the tropics. Renewable Sustainable Energy Rev., 31: 736-745.

Ogbeba, J.E. and E. Hoskara, 2019. The evaluation of single-family detached housing units in terms of integrated photovoltaic shading devices: The case of Northern Cyprus. Sustainability, Vol. 11, No. 3. $10.3390 /$ sul 1030593

Ohijeagbon, O.D. and O.O. Ajayi, 2014. Potential and economic viability of standalone hybrid systems for a rural community of Sokoto, North-west Nigeria. Front. Energy, 8: 145-159.

Okello, D., E.E. van Dyk and F.J. Vorster, 2015. Analysis of measured and simulated performance data of a $3.2 \mathrm{kWp}$ grid-connected PV system in Port Elizabeth, South Africa. Energy Convers. Manage., 100: 10-15.

Oliver, M. and T. Jackson, 2001. Energy and economic evaluation of building-integrated photovoltaics. Energy, 26: 431-439.

Osseweijer, F.J.W., L.B.P. van den Hurk, E.J. Teunissen and W.G. van Sark, 2018. A comparative review of building integrated photovoltaics ecosystems in selected European countries. Renewable Sustainable Energy Rev., 90: 1027-1040.

Ouria, M. and H. Sevinc, 2018. Evaluation of the potential of solar energy utilization in Famagusta, Cyprus. Sustainable Cities Soc., 37: 189-202.

Owusu, P.A. and S. Asumadu-Sarkodie, 2016. A review of renewable energy sources, sustainability issues and climate change mitigation. Cogent Eng., Vol. 3, No. 1. $10.1080 / 23311916.2016 .1167990$ 
Ozerdem, O.C., S. Tackie and S. Biricik, 2015. Performance evaluation of Serhatkoy (1.2 MW) PV power plant. Proceedings of the 2015 9th International Conference on Electrical and Electronics Engineering (ELECO), November 26-28, 2015, IEEE, Bursa, Turkey, pp: 398-402.

Pavlovic, T.M., D.D. Milosavljevic and D.S. Pirsl, 2013. Simulation of photovoltaic systems electricity generation using homer software in specific locations in Serbia. Therm. Sci., 17: 333-347.

Perera, F., 2018. Pollution from fossil-fuel combustion is the leading environmental threat to global pediatric health and equity: Solutions exist. Int. J. Environ. Res. Publ. Health, Vol. 15, No. 1. 10.3390/ijerph15010016

Psomopoulos, C.S., G.C. Ioannidis, S.D. Kaminaris, K.D. Mardikis, N.G. Katsikas, 2015. A comparative evaluation of photovoltaic electricity production assessment software (PVGIS, PVWatts and RETScreen). Environ. Processes, 2: 175-189.

Salem, T. and E. Kinab, 2015. Analysis of building-integrated photovoltaic systems: A case study of commercial buildings under Mediterranean Climate. Procedia Eng., 118: 538-545.

Shahzad, M.K., A. Zahid, T. Ur Rashid, M.A. Rehan, M. Ali and M. Ahmad, 2017. Techno-economic feasibility analysis of a solar-biomass off grid system for the electrification of remote rural areas in Pakistan using HOMER software. Renewable Energy, 106: 264-273.

Sharma, R. and S. Goel, 2017. Performance analysis of a $11.2 \mathrm{kWp}$ roof top grid-connected PV system in Eastern India. Energy Rep., 3: 76-84.

Sharma, V. and S.S. Chandel, 2013. Performance analysis of a $190 \mathrm{kWp}$ grid interactive solar photovoltaic power plant in India. Energy, 55: 476-485.

Singh, G.K., 2013. Solar power generation by PV (photovoltaic) technology: A review. Energy, 53: 1-13.

Sorrell, S., 2015. Reducing energy demand: A review of issues, challenges and approaches. Renewable Sustainable Energy Rev., 47: 74-82.
Sudhakar, K., P. Baredar and A.K. Shukla, 2016. Simulation and performance analysis of $110 \mathrm{kWp}$ grid-connected photovoltaic system for residential building in India: A comparative analysis of various PV technology. Energy Rep., 2: 82-88.

Sundaram, S. and J.S.C. Babu, 2015. Performance evaluation and validation of $5 \mathrm{MWp}$ grid connected solar photovoltaic plant in South India. Energy Convers. Manage., 100: 429-439.

Vares, S., T. Hakkinen, J. Ketomaki, J. Shemeikka and N. Jung, 2019. Impact of renewable energy technologies on the embodied and operational GHG emissions of a nearly zero energy building. J. Build. Eng., 22: 439-450.

Wang, W., Y. Liu, X. Wu, Y. Xu, W. Yu, C. Zhao and $Y$. Zhong, 2016. Environmental assessments and economic performance of BAPV and BIPV systems in Shanghai. Energy Build., 130: 98-106.

Wu, X., Y. Liu, J. Xu, W. Lei and X. Si et al., 2015. Monitoring the performance of the Building Attached PhotoVoltaic (BAPV) system in Shanghai. Energy Build., 88: 174-182.

Yang, R.J. and P.X.W. Zou, 2016. Building Integrated Photo Voltaics (BIPV): Costs, benefits, risks, barriers and improvement strategy. Int. J. Constr. Manage., 16: $39-53$.

Yang, R.J., 2015. Overcoming technical barriers and risks in the application of Building Integrated PhotoVoltaics (BIPV): Hardware and software strategies. Autom. Constr., 51: 92-102.

Zhou, C., R. Liang, J. Zhang and A. Riaz, 2017. Experimental study on dynamic thermal response of Building Attached Photo Voltaic (BAPV) curtain wall system. Procedia Eng., 205: 314-320.

Zomer, C.D., M.R. Costa, A. Nobre and R. Ruther, 2013. Performance compromises of building-integrated and building-applied photovoltaics (BIPV and BAPV) in Brazilian Airports. Energy Build., 66: 607-615. 